\title{
Cerebral Sinus Venous Thrombosis in Children with Inherited Bleeding Disorders - a Case Series
}

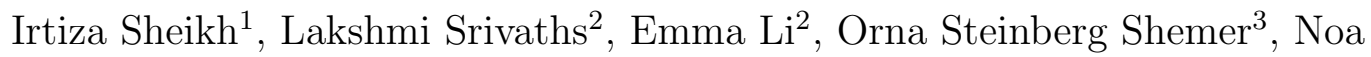 \\ Mandel-Shorer ${ }^{4}$, Gili Kenet ${ }^{5}$, and Assaf Barg ${ }^{5}$ \\ ${ }^{1} \mathrm{MD}$ Anderson Cancer Center \\ ${ }^{2}$ The University of Texas Health Science Center at Houston John P and Katherine G \\ McGovern Medical School \\ ${ }^{3}$ The Schneider Medical Center of Israel \\ ${ }^{4}$ Ruth Rappaport Children's Hospital \\ ${ }^{5}$ Chaim-Sheba Medical Center
}

February 8, 2022

\begin{abstract}
In patients with inherited bleeding disorders, thrombus development poses a challenge in balancing the management of thrombosis and bleeding. Pediatric antithrombotic therapy guidelines do not address the treatment of a thrombus in the setting of a bleeding disorder. We present a case series of four children with inherited bleeding disorders presenting with cerebral sinus venous thrombosis and bleeding, in order to summarize the different therapeutic approaches and outcomes of these patients.
\end{abstract}

\section{Introduction}

Acute thrombosis in patients with an inherited bleeding disorder (BD) represents a need to balance treating a thrombus with anticoagulation while maintaining adequate hemostasis ${ }^{1}$. This is important in managing a critical thrombus such as a cerebral sinus venous thrombosis (CSVT), especially following trauma, when the risk of intracranial hemorrhage (ICH) is significantly heightened ${ }^{2,3}$. In children with BDs, there are no standard guidelines that direct management of thrombosis ${ }^{4}$. Literature regarding the treatment of CSVT is variable, with studies demonstrating good neurological outcomes and thrombus resolution without anticoagulation therapy as well as studies indicating CSVT propagation in over $1 / 3$ of children not treated with anticoagulation therapy ${ }^{5-7}$. Here we present the management and outcome of four children with inherited BDs who developed trauma related CSVT. A summary of lab values, management, complications, and outcomes are provided in Table 1.

\section{Case Descriptions}

Case 1

A 5-year-old female with mild hemophilia A, with baseline FVIII level of $28 \%$, presented to the emergency department (ED) twelve hours following a fall of four feet, with trauma to the back of her head ${ }^{8}$. She developed altered mentation, severe occipital headache, and multiple episodes of vomiting prior to presentation. A computerized tomography (CT) scan without contrast of the head and CT venography (CTV) were obtained, showing extra-axial hemorrhage of the left occipital region and CSVT (Figure 1). Due to worsening headache, and increase in ICH, the patient was started on scheduled intravenous short-acting recombinant FVIII infusions. She was discharged eleven days after admission, and completed total of 14 days of factor therapy. Post discharge, after ICH stabilized on repeat imaging, the patient was started 
on subcutaneous enoxaparin therapy with concurrent prophylaxis with long acting FVIII. Magnetic resonance imaging/magnetic resonance venography (MRI/MRV) of the head following 6 weeks of anticoagulation therapy showed complete resolution of the CSVT and ICH.

Case 2

A 2-year-old female with no known PMH presented to the ED following head injury due to an accidental fall ${ }^{8}$. Initial head CT scan was normal; the patient developed somnolence and recurrent vomiting over the next day, prompting a CTV which showed left sigmoid sinus and internal jugular (IJ) vein thrombosis. The patient was transferred to the pediatric intensive care unit (PICU) and started on unfractionated heparin (UFH) drip and transitioned to enoxaparin treatment after 72 hours with therapeutic anti-Xa level of $0.53 \mathrm{IU} / \mathrm{ml}$. After 3 days of enoxaparin, the patient was found to have an intra-abdominal bleed as evidenced on abdominal ultrasound (US) and abdominal CT. The enoxaparin treatment was held, and to rapidly control the bleed, she was administered protamine sulfate for enoxaparin reversal, IV vitamin $\mathrm{K}$ for potential deficiency-related coagulopathy, and red blood cell transfusion for a hemoglobin of $5.3 \mathrm{~g} / \mathrm{dl}$. Factor VIII level was later found to be low at $24 \%$ without inhibitor, indicating the patient had mild Hemophilia A ${ }^{8}$. Follow-up abdominal US performed a week later showed a hematoma at the root of the mesentery, indicating an accelerationdeceleration injury to her abdomen sustained during the fall, leading to a tear in the root of the mesentery. An MRI/MRV performed 2 weeks after presentation showed no worsening of the CSVT. Anticoagulation treatment was not renewed due to the major abdominal bleed. Repeat MRI/MRV scans performed 3 weeks and 4 months following presentation, showed complete thrombus resolution.

Case 3

An 8-year-old male with type 3 von Willebrand disease (VWD), on demand therapy with VW Factor (VWF) concentrate presented to the ED following head trauma due to a fall from a height of 4 feet. His physical exam showed left parietal scalp hematoma, a head CT scan without contrast showed linear left parietal fracture with small subarachnoid contrecoup bleeding (Table 1). The patient was started on IV VWF concentrate, Haemate-P at 50 units $/ \mathrm{kg}$, administered three times a week. Five days following the fall, CTV was obtained for worsening headache. Due to development of new CSVT (left epidural and sagittal vein thromboses), VWF concentrate was discontinued, and anticoagulation therapy was withheld due to risk of worsening bleeding. Two days later, the headache subsided and MRV demonstrated no further bleeding with partial improvement of CSVT. Another MRV obtained a month later demonstrated resolution of the hematoma and complete recanalization of the sagittal sinus thrombosis.

\section{Case 4}

A 7-year-old male with no significant past medical history was evaluated for increasing headache four days following an occipital head injury due to an accidental fall. Physical exam showed parieto-occipital hematoma with normal neurological function. A head CT scan showed transverse sinus thrombosis and an epidural bleed. The patient was admitted to the PICU for planned anticoagulation treatment with unfractionated heparin (UFH). However, labs prior to initiation of therapy showed prolonged aPTT and anticoagulation therapy was withheld. Further laboratory evaluation confirmed diagnosis of severe FXI deficiency (FXI level of $4 \%$ ). An MRI of the brain performed after a month showed absorption of the hematoma and complete recanalization of the CSVT.

\section{Discussion}

We present four pediatric patients with BDs and CSVT, which required balancing the need for hemostasis in the setting of an intracranial/abdominal bleed while avoiding the propagation of CSVT. Thrombus development in patients with inherited BDs most commonly occurs due to the presence of a central venous catheter, iatrogenic development due to factor therapy, or presence of underlying prothrombotic gene mutations ${ }^{9}$. The development of CSVT following a closed head injury is uncommon but can occur in the presence of a skull fracture or hematoma that leads to compression of the cerebral sinuses ${ }^{10,11}$. There is currently no literature addressing the presence or management of a post-traumatic CSVT in pediatric patients with inherited BDs. 
Standard guidelines that direct management of thromboembolism in children with hemophilia are lacking ${ }^{1}$. Many factors should be taken into account when anticoagulating a patient with hemophilia, including the severity of bleeding and thrombosis, and the type and duration of anticoagulant therapy. When using easily reversible anticoagulants while maintaining FVIII/FIX levels $>30 \%$, anticoagulation has been found to be safe in hemophilia, with some reports recommending shorter duration of 6 to 8 weeks for provoked thrombosis while others employing the "shortest duration" necessary until thrombus resolution ${ }^{1,12}$.

Reports of thrombus development in patients with VWD including type 3 VWD, are rare ${ }^{13}$. VWF concentrates have been shown to contribute to thrombus development in patients with $\mathrm{VWD}^{14}$. It is possible that in our patient with type $3 \mathrm{VWD}$, VWF concentrate, along with trauma, was a contributing factor in thrombus formation. This may be supported by the fact that upon cessation of VWF concentrate, CSVT improved within 3 days, with complete resolution within a month despite no anticoagulation therapy. Notably, with administration of VWF concentrate, levels of VWF and FVIII:C should be monitored to guide treatment and avoid supratherapeutic levels that may increase the risk for thrombosis ${ }^{15}$.

FXI demonstrates properties as a procoagulant and inhibits fibrinolysis whereas deficiency has been found to provide protection against thrombus formation in animal models and humans ${ }^{16,17}$. Moreover, inhibition of FXI has been shown to serve as effective thromboprophylaxis ${ }^{18}$. For these reasons, it is plausible that low levels of FXI in patient 3 facilitated thrombus resolution despite no anticoagulation.

While the development of CSVT in children with inherited BDs is uncommon, the management of such thrombi are based on adult experience indicating that short duration anticoagulation with concurrent factor prophylaxis may be feasible with close monitoring of factor levels and intracranial imaging ${ }^{19,20}$. As patients 2, 3, and 4 had CSVT resolution without anticoagulation, watchful observation may be an alternative approach for managing CSVT in these patients, especially in the setting of ICH, and anticoagulation reserved for worsening clinical and/or imaging findings of CSVT. ${ }^{6}$. Prospective studies are required to determine the risks and outcomes associated with withholding versus administering anticoagulation therapy in pediatric patients with inherited BDs and CSVT.

\section{Conclusion}

Our case series shows that in children with inherited BD who develop CSVT, watchful waiting, discontinuation of anticoagulation, or delayed start of anticoagulation therapy after control of bleeding, with careful balancing of bleeding versus thrombosis with concurrent use of factor therapy with anticoagulation, may be safe therapeutic approaches.

Table 1. Clinical Features of patients with inherited BDs with CSVT and ICH 


\begin{tabular}{|c|c|c|c|c|c|c|c|}
\hline Patient & $\begin{array}{l}\text { Age } \\
\text { (years), } \\
\text { Gender }\end{array}$ & $\begin{array}{l}\text { Inherited } \\
\text { bleeding } \\
\text { disorder }\end{array}$ & $\begin{array}{l}\text { Lab } \\
\text { findings }\end{array}$ & $\begin{array}{l}\text { Imaging } \\
\text { findings }\end{array}$ & $\begin{array}{l}\text { Treatment } \\
\text { for bleed }\end{array}$ & $\begin{array}{l}\text { Treatment } \\
\text { for CSVT }\end{array}$ & $\begin{array}{l}\text { Outcome } \\
\text { of bleed } \\
\text { and CSVT }\end{array}$ \\
\hline 1 & $5, \mathrm{~F}$ & $\begin{array}{l}\text { Mild } \\
\text { Hemophilia } \\
\text { A }\end{array}$ & $\begin{array}{l}\text { Baseline: } \\
\text { Factor VIII } \\
\text { level: } 28 \% \\
\text { (normal } \\
\text { range: } \\
\text { 50-242\%) } \\
\text { Following } \\
\text { recombinant } \\
\text { FVIII } \\
\text { therapy: } \\
\text { FVIII level: } \\
\text { Trough: } \\
\text { 85\% Peak: } \\
\text { 160\% } \\
\text { Following } \\
\text { enoxaparin } \\
\text { therapy: } \\
\text { Anti-Xa } \\
\text { level: 0.43 } \\
\text { IU/mL }\end{array}$ & $\begin{array}{l}\text { CT: Extra } \\
\text { axial } \\
\text { subdural } \\
\text { hematoma } \\
\text { of the left } \\
\text { parieto- } \\
\text { occipital } \\
\text { region CTV: } \\
\text { nearly } \\
\text { complete } \\
\text { occlusion of } \\
\text { the left } \\
\text { sigmoid } \\
\text { venous sinus } \\
\text { and left } \\
\text { upper } \\
\text { internal } \\
\text { jugular } \\
\text { consistent } \\
\text { with CSVT }\end{array}$ & $\begin{array}{l}\text { IV Recombi- } \\
\text { nant FVIII } \\
\text { at } 50 \mathrm{u} / \mathrm{kg} \\
\text { every } 8 \\
\text { hours for } 14 \\
\text { days } \\
\text { followed by } \\
\text { long acting } \\
\text { FVIII } \\
\text { prophylaxis } \\
\text { of } 65 \mathrm{u} / \mathrm{kg} \\
\text { weekly for } 6 \\
\text { weeks }\end{array}$ & $\begin{array}{l}\text { Subcutaneous } \\
\text { Enoxaparin } \\
\text { therapy } \\
\text { twice daily } \\
\text { for } 6 \text { weeks }\end{array}$ & $\begin{array}{l}\text { Complete } \\
\text { resolution of } \\
\text { subdural } \\
\text { hematoma } \\
\text { and CSVT, } \\
8 \text { weeks after } \\
\text { presentation }\end{array}$ \\
\hline
\end{tabular}




\begin{tabular}{|c|c|c|c|c|c|c|c|}
\hline Patient & $\begin{array}{l}\text { Age } \\
\text { (years), } \\
\text { Gender }\end{array}$ & $\begin{array}{l}\text { Inherited } \\
\text { bleeding } \\
\text { disorder }\end{array}$ & $\begin{array}{l}\text { Lab } \\
\text { findings }\end{array}$ & $\begin{array}{l}\text { Imaging } \\
\text { findings }\end{array}$ & $\begin{array}{l}\text { Treatment } \\
\text { for bleed }\end{array}$ & $\begin{array}{l}\text { Treatment } \\
\text { for CSVT }\end{array}$ & $\begin{array}{l}\text { Outcome } \\
\text { of bleed } \\
\text { and CSVT }\end{array}$ \\
\hline 2 & $2, \mathrm{~F}$ & $\begin{array}{l}\text { Mild } \\
\text { Hemophilia } \\
\text { A }\end{array}$ & $\begin{array}{l}\text { Baseline: } \\
\text { Factor VIII } \\
\text { level: } 24 \% \\
\text { (normal } \\
\text { range: } \\
\text { 50-242\%) } \\
\text { aPTT: } 42 \\
\text { seconds } \\
\text { (normal } \\
\text { range: } \\
22.9-35.8 \\
\text { seconds) } \\
\text { Pre-bleed: } \\
\text { Anti-Xa } \\
\text { level: } 0.53 \\
\text { IU/mL } \\
\text { Following } \\
\text { abdominal } \\
\text { bleed: } \\
\text { Hemoglobin: } \\
5.3 \text { g/dl } \\
\text { Platelets: } \\
298,000 / m i- \\
\text { croliter PT: } \\
\text { 16.1 seconds } \\
\text { aPTT: } 39.8 \\
\text { seconds INR } \\
: 1.38 \\
\text { Anti-Xa } \\
\text { level: } 0.38 \\
\text { IU/mL } \\
\text { Following } \\
\text { bleeding } \\
\text { intervention: } \\
\text { Hemoglobin: } \\
\text { 8.6 g/dL } \\
\text { aPTT: } 29.6 \\
\text { seconds }\end{array}$ & $\begin{array}{l}\text { CTV: Left } \\
\text { sigmoid } \\
\text { sinus and } \\
\text { internal } \\
\text { jugular vein } \\
\text { thrombosis } \\
\text { Abdominal } \\
\text { US and CT: } \\
\text { Significant } \\
\text { free fluid in } \\
\text { the } \\
\text { abdomen } \\
\text { and pelvis } \\
\text { indicative of } \\
\text { an } \\
\text { abdominal } \\
\text { bleed } \\
\text { Repeat } \\
\text { abdominal } \\
\text { US (1week } \\
\text { after presen- } \\
\text { tation): } \\
\text { hematoma } \\
\text { at the root } \\
\text { of the } \\
\text { mesentery }\end{array}$ & $\begin{array}{l}\text { Protamine } \\
\text { sulfate, IV } \\
\text { vitamin } \mathrm{K} \\
(0.3 \mathrm{mg} / \mathrm{kg}) \text {, } \\
15 \mathrm{ml} / \mathrm{kg} \text { of } \\
\text { packed red } \\
\text { blood cells }\end{array}$ & $\begin{array}{l}\text { UFH } \\
\text { followed by } \\
\text { twice daily } \\
\text { subcuta- } \\
\text { neous } \\
\text { enoxaparin. } \\
\text { Enoxaparin } \\
\text { held } \\
\text { following } \\
\text { discovery of } \\
\text { acute } \\
\text { abdominal } \\
\text { bleed } 3 \text { days } \\
\text { after } \\
\text { starting }\end{array}$ & $\begin{array}{l}\text { Complete } \\
\text { resolution of } \\
\text { the left } \\
\text { sigmoid } \\
\text { sinus and IJ } \\
\text { vein } \\
\text { thrombosis } \\
\text { at } 4 \text { months } \\
\text { after } \\
\text { presentation }\end{array}$ \\
\hline
\end{tabular}




\begin{tabular}{|c|c|c|c|c|c|c|c|}
\hline Patient & $\begin{array}{l}\text { Age } \\
\text { (years), } \\
\text { Gender }\end{array}$ & $\begin{array}{l}\text { Inherited } \\
\text { bleeding } \\
\text { disorder }\end{array}$ & $\begin{array}{l}\text { Lab } \\
\text { findings }\end{array}$ & $\begin{array}{l}\text { Imaging } \\
\text { findings }\end{array}$ & $\begin{array}{l}\text { Treatment } \\
\text { for bleed }\end{array}$ & $\begin{array}{l}\text { Treatment } \\
\text { for CSVT }\end{array}$ & $\begin{array}{l}\text { Outcome } \\
\text { of bleed } \\
\text { and CSVT }\end{array}$ \\
\hline \multirow[t]{2}{*}{3} & $8, \mathrm{M}$ & $\begin{array}{l}\text { Von } \\
\text { Willebrand } \\
\text { Disease, } \\
\text { Type } 3\end{array}$ & $\begin{array}{l}\text { Baseline: } \\
\text { Factor VIII } \\
\text { level: } 10 \% \\
\text { (normal } \\
\text { range: } \\
\text { 50-242\%) } \\
\text { Von } \\
\text { Willebrand } \\
\text { factor } \\
\text { (VWF) } \\
\text { antigen: } 8 \% \\
\text { (normal } \\
\text { range: } \\
22.9-35.8 \% \text { ) } \\
\text { Ristocetin } \\
\text { co-factor: } \\
7 \% \text { (normal } \\
\text { range: } \\
\text { 40-130\%) } \\
\text { Following } \\
\text { initiation of } \\
\text { VWF } \\
\text { concentrate } \\
\text { treatment } \\
\text { (trough } \\
\text { level): VWF } \\
\text { antigen: } \\
32 \% \\
\text { Ristocetin } \\
\text { cofactor: } \\
21 \% \text { FVIII } \\
\text { level: } 45 \% \\
\text { (n) }\end{array}$ & $\begin{array}{l}\text { CT: Linear } \\
\text { left parietal } \\
\text { fracture } \\
\text { with small } \\
\text { subarach- } \\
\text { noid } \\
\text { contrecoup } \\
\text { bleeding } \\
\text { CTV (5 } \\
\text { days after } \\
\text { fall): New } \\
\text { left epidural } \\
\text { and left } \\
\text { sagittal vein } \\
\text { thrombosis, } \\
\text { resolution of } \\
\text { bleeding }\end{array}$ & $\begin{array}{l}\text { IV VWF } \\
\text { concentrate } \\
\text { three times } \\
\text { a week, } \\
\text { discontinued } \\
\text { following } \\
\text { development } \\
\text { of thrombus }\end{array}$ & None & $\begin{array}{l}\text { Complete } \\
\text { resolution of } \\
\text { subarach- } \\
\text { noid } \\
\text { bleeding and } \\
\text { CSVT, } 1 \\
\text { month after } \\
\text { presentation }\end{array}$ \\
\hline & $7, \mathrm{M}$ & $\begin{array}{l}\text { Factor XI } \\
\text { deficiency }\end{array}$ & $\begin{array}{l}\text { aPTT: } 82 \\
\text { seconds FXI } \\
\text { level: } 4 \% \\
\text { (normal } \\
\text { range: } \\
50-200 \% \text { ) }\end{array}$ & $\begin{array}{l}\text { CT: } \\
\text { Transverse } \\
\text { sinus } \\
\text { thrombosis } \\
\text { and epidural } \\
\text { bleed CTV } \\
\text { (48 hours } \\
\text { after fall): } \\
\text { Hematoma } \\
\text { mass effect } \\
\text { without } \\
\text { clear } \\
\text { intraluminal } \\
\text { thrombosis }\end{array}$ & $\begin{array}{l}\text { Watchful } \\
\text { waiting }\end{array}$ & None & $\begin{array}{l}\text { Complete } \\
\text { resolution of } \\
\text { epidural } \\
\text { hematoma } \\
\text { and CSVT } 1 \\
\text { month after } \\
\text { presentation }\end{array}$ \\
\hline
\end{tabular}


aPTT - activated partial thromboplastin time; BD - Bleeding Disorder; CSVT - Cerebral sinus venous thrombosis; ICH - Intracranial hemorrhage; CT - Computed tomography; CTV - Computed tomography venogram ; IV - Intravenous; F VIII - Factor VIII; VWF - von Willebrand Factor; Factor XI - F XI; US-ultrasound; IJ-Internal jugular; IU-International unit; mL-milliliter

Figure 1. Five year old patient, later found to have Hemophilia presenting to the emergency department (ED) due to a fall of four feet leading to trauma at the posterior portion of the skull. A) Computed tomography $(\mathrm{CT})$ of the head after admission indicating signs of a parieto-occipital hematoma (indicated by arrow). B) Magenetic resonance venography indicating signs of extra-axial hemorrahge as well as narrowing and displacement of the left transverse sinus due to an adjacent thrombus. C) Magnetic resonance angiography obtained outpatient indicating resolution of bleeding and sinus thromboses eight weeks following presentation.
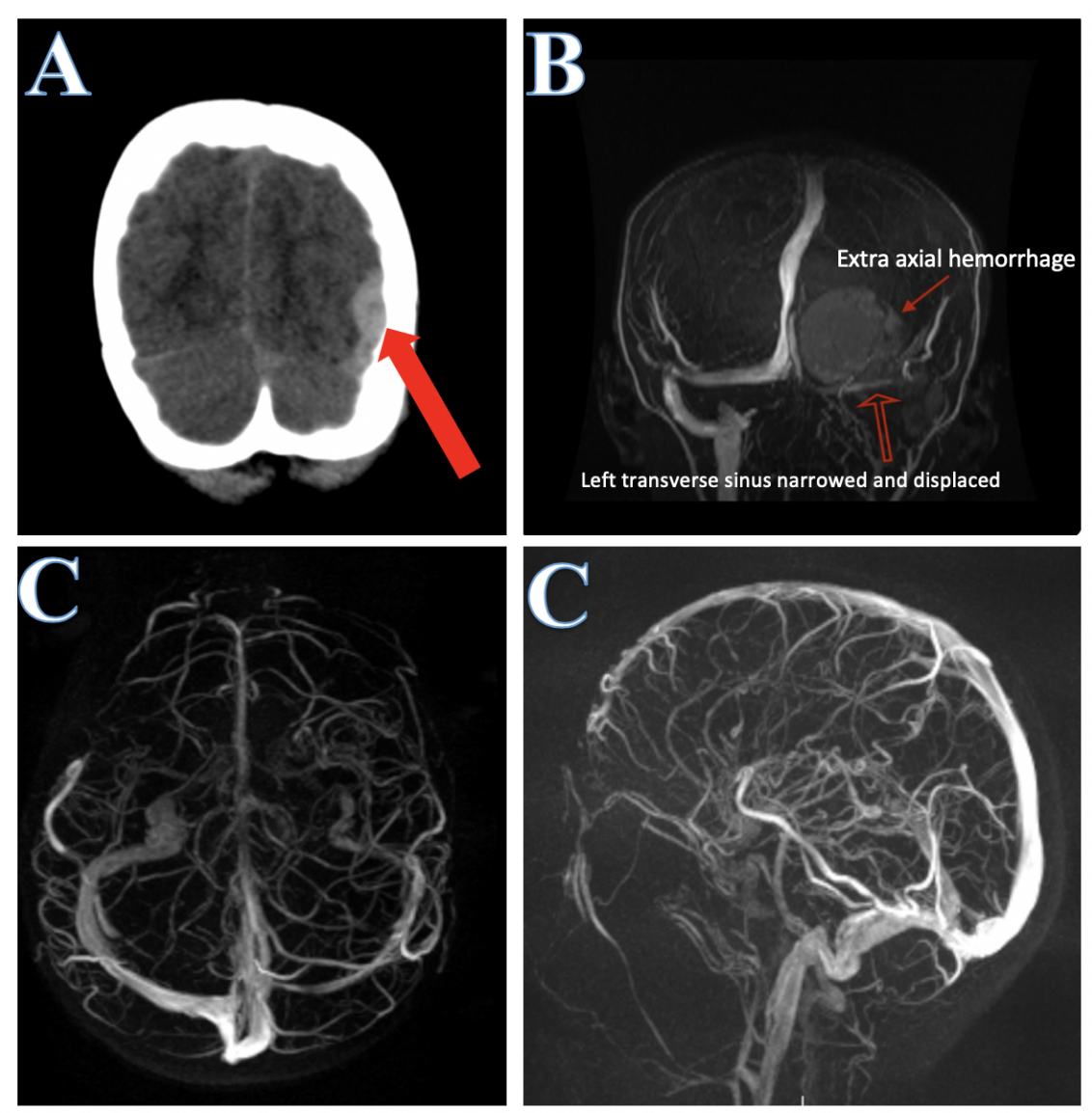

\section{References}

1. Martin K, Key NS. How I treat patients with inherited bleeding disorders who need anticoagulant therapy. Blood.2016;128(2):178-184.

2. Dietrich AM, James CD, King DR, Ginn-Pease ME, Cecalupo AJ. Head trauma in children with congenital coagulation disorders. Journal of Pediatric Surgery. 1994;29(1):28-32.

3. Klinge J, Auberger K, Auerswald G, et al. Prevalence and outcome of intracranial haemorrhage in haemophiliacs - a survey of the paediatric group of the German Society of Thrombosis and Haemostasis (GTH).European Journal of Pediatrics. 1999;158(3):S162-S165. 
4. Girolami A, Bertozzi I, de Marinis GB, Tasinato V, Sambado L. Discrepant ratios of arterial versus venous thrombosis in hemophilia A as compared with hemophilia B. Journal of Thrombosis and Thrombolysis. 2014;37(3):293-297.

5. Bokhari R, You E, Bakhaidar M, et al. Dural Venous Sinus Thrombosis in Patients Presenting with Blunt Traumatic Brain Injuries and Skull Fractures: A Systematic Review and Meta-Analysis. World Neurosurg. 2020;142:495-505.e493.

6. Mansour G, Barsky D, Abuhasira S, et al. Traumatic cerebral dural sinus vein thrombosis/stenosis in pediatric patients - is anticoagulation necessary? Child's Nervous System.2021;37(9):2847-2855.

7. Moharir MD, Shroff M, Stephens D, et al. Anticoagulants in pediatric cerebral sinovenous thrombosis: A safety and outcome study. Annals of Neurology. 2010;67(5):590-599.

8. van Galen KPM, d'Oiron R, James P, et al. A new hemophilia carrier nomenclature to define hemophilia in women and girls: Communication from the SSC of the ISTH. J Thromb Haemost. 2021;19(8):1883-1887.

9. Franchini M. Thrombotic complications in patients with hereditary bleeding disorders. Thromb Haemost. 2004;92(2):298-304.

10. Stiefel D, Eich G, Sacher P. Posttraumatic dural sinus thrombosis in children. Eur J Pediatr Surg. 2000;10(1):41-44.

11. Hersh DS, Shimony N, Groves ML, et al. Pediatric cerebral venous sinus thrombosis or compression in the setting of skull fractures from blunt head trauma. J Neurosurg Pediatr. 2018;21(3):258-269.

12. Srivastava A, Santagostino E, Dougall A, et al. WFH Guidelines for the Management of Hemophilia, 3rd edition. Haemophilia.2020;26(S6):1-158.

13. Girolami A, Tezza F, Scapin M, Vettore S, Casonato A. Arterial and venous thrombosis in patients with von Willebrand's disease: a critical review of the literature. J Thromb Thrombolysis.2006;21(2):175-178.

14. Makris M, Colvin B, Gupta V, Shields ML, Smith MP. Venous thrombosis following the use of intermediate purity FVIII concentrate to treat patients with von Willebrand's disease. Thromb Haemost.2002;88(3):387-388.

15. Franchini M. Thrombotic complications in von Willebrand disease.Hematology. 2006;11(1):49-52.

16. Ruiz-Saez A. Occurrence of thrombosis in rare bleeding disorders. Semin Thromb Hemost. 2013;39(6):684692.

17. Salomon O, Steinberg DM, Zucker M, Varon D, Zivelin A, Seligsohn U. Patients with severe factor XI deficiency have a reduced incidence of deep-vein thrombosis. Thromb Haemost. 2011;105(2):269-273.

18. Verhamme P, Yi BA, Segers A, et al. Abelacimab for Prevention of Venous Thromboembolism. New England Journal of Medicine.2021;385(7):609-617.

19. Ichord R. Cerebral Sinovenous Thrombosis. Frontiers in Pediatrics. 2017;5(163).

20. Monagle P, Chan AKC, Goldenberg NA, et al. Antithrombotic Therapy in Neonates and Children: Antithrombotic Therapy and Prevention of Thrombosis, 9th ed: American College of Chest Physicians Evidence-Based Clinical Practice Guidelines. CHEST. 2012;141(2):e737S-e801S. 
Figure 1. Five year old patient, later found to have Hemophilia presenting to the emergency department (ED) due to a fall of four feet leading to trauma at the posterior portion of the skull. A) Computed tomography (CT) of the head after admission indicating signs of a parieto-occipital hematoma (indicated by arrow). B) Magenetic resonance venography indicating signs of extraaxial hemorrahge as well as narrowing and displacement of the left transverse sinus due to an adjacent thrombus. C) Magnetic resonance angiography obtained outpatient indicating resolution of bleeding and sinus thromboses eight weeks following presentation.
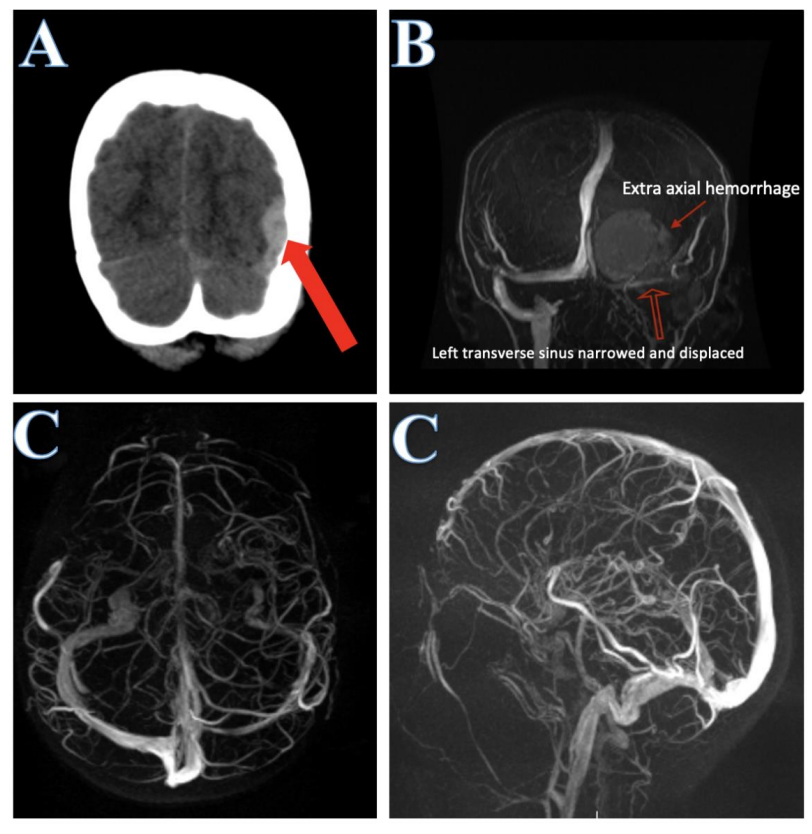

\section{Hosted file}

IBD Table 1 CSVT.docx available at https://authorea.com/users/436621/articles/555682cerebral-sinus-venous-thrombosis-in-children-with-inherited-bleeding-disorders-a-caseseries 